\title{
KEWAJIBAN PEMBAYARAN ROYALTI TERHADAP COVER LAGU MILIK MUSISI INDONESIA
}

\author{
Dewa Gede Jeremy Zefanya, Fakultas Hukum Universitas Udayana, e-mail: \\ jeremy.ajus@gmail.com \\ A.A Sri Indrawati, Fakultas Hukum Universitas Udayana, e-mail: \\ agusngsri_indrawati@unud.ac.id
}

doi: https://doi.org/10.24843/KS.2020.v08.i12.p08

\begin{abstract}
ABSTRAK
Tujuan dari penulisan ini untuk mengetahui pengaturan terkait dengan kewajiban pembayaran royalti terhadap perbuatan mengcover lagu musisi indonesia berdasarkan ketentuan Undang-Undang No. 28 Tahun 2014 tentang Hak Cipta dan akibat hukum yang ditimbulkan apabila para pihak menolak membayar royalti kepada musisi selaku pencipta lagu dan musik. Metode penelitian yang digunakan dalam tulisan ini adalah penelitian hukum normatif dengan menggunakan pendekatan perundangundangan dan mengkaji dari literatur-literatur kepustakaan. Hasil studi menunjukkan bahwa perlindungan atas Hak Kekayaan Intelektual ini dilakukan dengan tujuan memberikan suatu penghargaan kepada kelompok atau perseorangan yang telah memberikan ide dan gagasannya dalam menciptakan sebuah karya Dalam perkembangannya, industri digital telah mengalami pasang surut khususnya yang dirasakan oleh para musisi. Musisi yang juga sekaligus sebagai pencipta, penyanyi, pemusik dan bahkan produser dari rekaman suara ataupun video klipnya dapat mendistribusikan karyanya bukan hanya melalui $C D$ dan radio, namun juga dapat mengunggahnya ke media internet untuk dipublikasikan serta mendapatkan royalti. Penggunaan lagu secara komersial tidak dianggap sebagai pelanggaran Hak Cipta asalkan pengguna memenuhi kewajiban mereka berdasarkan perjanjian dengan Lembaga Manajemen Kolektif (LMK) untuk membayar lagu royalty berdasarkan pasal 87 ayat (4) Undang-Undang No.28 Tahun 2014 tentang Hak Cipta. LMK selaku penerima kuasa dari pencipta lagu memiliki kewenangan untuk melaporkan pihak (users) tersebut ke pihak yang berwenang bahwa telah terjadi pelanggaran penggunaan hak cipta lagu dan musik untuk kepentingan komersial.
\end{abstract}

Kata Kunci: Hak Cipta, Royalti, Cover Lagu

\begin{abstract}
The purpose expected in this writing is to find out the legal protection regarding the obligation to pay royalties for covering songs by Indonesian musicians based on the provisions of Law no. 28 of 2014 concerning Copyright and the legal consequences that arise if the parties refuse to pay royalties to musicians as song and music composers. The research method used in this paper is normative legal research using a statutory approach and reviewing the literature literature. The results of the study show that the protection of Intellectual Property Rights is carried out with the aim of giving an award to groups or individuals who have given their ideas and ideas in creating a work. In its development, the digital industry has experienced ups and downs, especially those felt by musicians. Musicians who are also creators, singers, musicians and even producers of sound recordings or video clips can distribute their works not only via $C D$ and radio, but can also upload them to the internet for publication and get royalties. Commercial use of songs is not considered a copyright infringement as long as users fulfill their obligations under the agreement with the Collective Management Institute (LMK) to pay for royalty songs based on article 87 paragraph (4) of Law No. 28 of 2014 concerning Copyright. LMK as the recipient of power from the songwriter has the authority to report the users to the authorities that there has been a violation of the use of song and music copyright for commercial purposes.
\end{abstract}


Keywords: Copyright, Royalty, Cover Song.

\section{Pendahuluan}

\subsection{Latar Belakang}

Perkembangan teknologi memberikan banyak kemudahan bagi setiap orang untuk mengakses informasi di internet, internet adalah media online berupa saluran informasi tanpa batas yang bisa menyajikan banyak informasi bagi siapa saja. Informasi berupa tulisan, gambar, audio dan video dapat dengan mudah dijangkau kapan dan dimana saja. Hal ini memberikan peluang besar kepada berbagai macam industri untuk beralih dari industri konvesional menuju industri modern yang berbasiskan online.

Perkembangan teknologi yang cepat saat ini telah membawa banyak pengaruh terhadap bidang Hak Kekayaan Intelektual. ${ }^{1}$ Hak Kekayaan Intelektual adalah suatu hak yang lahir karena adanya hasil pemikiran yang menghasilkan suatu ide gagasan atau produk yang bermanfaat bagi manusia. Hak Kekayaan Intelektual bisa juga diartikan sebagai hak untuk kelompok atau perseorangan karena menghasilkan suatu yang berguna bagi orang lain. ${ }^{2}$ Perlindungan atas Hak Kekayaan Intelektual ini dilakukan dengan tujuan memberikan suatu penghargaan kepada kelompok atau perseorangan yang telah memberikan ide dan gagasannya dalam menciptakan sebuah karya. ${ }^{3}$ Dalam Supasti Dharmawan, Insan Budi Maulana mengatakan, "Hak Kekayaan Intelektual terdiri atas dua bagian besar yaitu pertama: hak kekayaan industrial yang berkaitan dengan hak dalam kegiatan industri dan yang kedua: hak cipta." 4 Hak Cipta merupakan hak atas suatu karya yang dimiliki oleh penciptanya, di Indonesia peraturan tentang Hak Cipta secara nasional diatur dalam Undang-Undang Nomor 28 Tahun 2014 Tentang Hak Cipta. Menurut Pasal 1 angka 1 Undang-Undang No.28 Tahun 2014 tentang Hak Cipta "Hak Cipta adalah hak yang dimiliki pencipta secara eksklusif yang timbul dengan berdasarkan prinsip deklaratif setelah suatu karya diwujudkan dalam bentuk nyata serta tanpa mengurangi pembatasan hak lainnya sesuai dengan ketentuan peraturan perundang-undangan". Melalui hak cipta, kemudian lahirlah hak moral dan hak ekonomi. Hak moral diatur dalam Pasal 5 ayat (1) UU No. 28 Tahun 2014 tentang Hak Cipta yang menjelaskan "Hak untuk tetap mencantumkan atau tidak mencantumkan nama kreator pada salinan sehubungan dengan pemakaian ciptaannya untuk umum, menggunakan nama samarannya, sampai mempertahankan haknya dalam hal terjadi distorsi, pemotongan, modifikasi, dan hal-hal lain yang bersifat merugikan kehormatan atau reputasi sang creator". Sedangkan Hak Ekonomi diatur dalam Pasal 8 UU No.28 Tahun 2014 Tentang Hak

1 Mieke Yustia Ayu Ratna Sari, 2016, "PEMBANGUNAN KEKAYAAN INTELEKTUAL (KI) BERBASIS TEKNOLOGI INFORMASI", Unisbank Semarang, h. 490-500.

2 Haris Munandar, dan Sally Sitanggang, 2012, Mengenal Hak Kekayaan Intelektual, Erlangga, Jakarta, Hlm. 2.

3 Putu Dina Amanda Swari, dan I Made Subawa. 2018, "PERLINDUNGAN HUKUM LAGU YANG DIUNGGAH TANPA IZIN PENCIPTA DI SITUS YOUTUBE". Jurnal Ilmiah Ilmu Hukum Kertha Semaya Hukum Udayana, Vol. 6, No. 10, h. 1-15.

4 Ni Ketut Supasti Dharmawan, et. al., 2018, Harmonisasi Hukum Kekayaan Intelektual Indonesia, SWASTA NULUS, Denpasar, h.20. 
Cipta yaitu "Meliputi penerbitan, penggandaan dalam segala bentuk, adaptasi, aransemen, transformasi, pendistribusian, hingga penyiaran atas ciptaannya" .5

Dunia yang kini telah memasuki era Revolusi Industri 4.0 memiliki dampak positif dan negatif terutama bagi pelaku industri. Revolusi Industri 4.0 adalah transformasi komprehensif dari seluruh aspek produksi di industri melalui penyatuan konsep teknologi digital dan internet dengan industri konvensional. ${ }^{6}$ Dalam perkembangannya, industri digital telah mengalami pasang surut khususnya yang dirasakan oleh para musisi. Musisi yang juga sekaligus sebagai pencipta, penyanyi, pemusik dan bahkan produser dari rekaman suara ataupun video klipnya dapat mendistribusikan karyanya bukan hanya melalui $\mathrm{CD}$ dan radio, namun juga dapat mengunggahnya ke media internet untuk dipublikasikan serta mendapatkan royalti (hak ekonomi). Banyak media di internet yang dapat digunakan untuk publikasi seperti radio online, media sosial, dan platform streaming video atau musik. Media tersebut sangat mudah diakses oleh semua orang baik dengan berlangganan ataupun gratis.

Lagu dan musik dalam kehidupan sehari-hari dipergunakan di berbagai kesempatan baik itu didengarkan, dgisiarkan, dipertunjukkan, serta disebarkan. Penggunaan media bukan hanya melalui televisi dan radio namun kini telah berkembang menggunakan smartphone. Penggunaan lagu dan musik yang diperdengarkan tersebut selalu disertai dengan aktivitas ekonomi, sebagai contoh membeli lagu di smartphone melalui aplikasi atau berlangganan aplikasi platform streaming music dan menonton video musik melalui aplikasi YouTube. Perkembangan teknologi terkait sarana untuk menikmati lagu dan musik tentu membawa dampak positif dan negatif. Dampak positifnya adalah masyarakat semakin mudah untuk menikmati musik, juga memudahkan pencipta dalam hal mempromosikan karyakaryanya, sedangkan dampak negatif yang timbul seperti banyak orang yang justru menyalahgunakan teknologi untuk kepentingan pribadi seperti melakukan pembajakan, dan yang terbaru adalah mendapatkan keuntungan berupa uang dari membuat cover video atau musik cover yang diunggah lagi ke internet dan media sosial.

Berdasarkan Pasal 4 Undang-Undang No. 28 Tahun 2014 tentang Hak Cipta menyatakan bahwa "Hak Cipta merupakan hak yang terdiri dari hak moral dan juga hak ekonomi" oleh sebab itu pencipta lagu selaku pemilik lagu itu sendiri berhak mendapatkan hak ekonomis dari hasil ciptaanya dengan pemberian berupa royalti yang diperoleh dari setiap orang yang mencover lagu milik musisi tersebut ketentuan tersebut diatu dalam Pasal 8 Undang-Undang No. 28 Tahun 2014 tentang Hak Cipta. Pasal 1 angka 21 Undang-Undang No. 28 Tahun 2014 tengtang Hak Cipta menyatakan bahwa "Royalti adalah imbalan atas pemanfaatan hak ekonomi suatu ciptaan atau suatu produk hak terkait yang diterima oleh pencipta atas pemilik hak terkait". ${ }^{7}$ Musisi selaku pencipta lagu dapat memberikan izin kepada pihak lain untuk

5 Kadek Julia Mahadewi, 2015 “Budaya Hukum Dalam Keberlakuan Undang-Undang Nomor 28 Tahun 2014 Tentang Hak Cipta Pada Pengerajin Perak Di Bali", Jurnal Magister Hukum Udayana Vol. 4, No. 2, h. 7-9.

6 Hoedi Prasetyo, dan Wahyudi Sutopo, 2018, "INDUSTRI 4.0: TELAAH KLASIFIKASI ASPEK DAN ARAH PERKEMBANGAN RISET". J@ti Undip: Jurnal Teknik Industri, Vol. 13, No. 1, h. 17-26.

7 Made Reditiya Abhi Pawitram, 2017, “Pengaturan Lembaga Manajemen Kolektif Berkaitan Dengan Penarikan Royalti Berdasarkan Undang-Undang Nomor 28 Tahun 2014 Tentang Hak Cipta", Jurnal Ilmiah Ilmu Hukum Kertha Semaya Hukum Udayana, Vol.5 , No.1, h.4. 
menggunakan karya cipta lagu atau musiknya dengan berupa pemberian izin lisensi. Lisensi merupakan "penjualan izin yang bersifat komersial untuk mempergunakan paten, hak atas merek, atau teknologi yang dilindungi secara ekonomis kepada pihak lain". 8

Untuk lagu cover yang dinyanyikan dengan tujuan komersil, pencantumman nama penyanyi asli saja pada lagu cover tentu tidak cukup untuk menghindarkan tuntutan hukum pemegang Hak Cipta. Agar tidak melanggar Hak Cipta orang lain untuk mereproduksi, merekam, mendistribusikan dan atau menyimpan sebuah lagu milik orang lain, terutama untuk tujuan komersil, seseorang perlu memperoleh izin atau lisensi dari pencipta atau pemegang Hak Cipta. Perilaku penyanyi pembuat lagu cover tanpa izin dari pemilik maupun pencipta lagu ini tanpa sadar telah sering terjadi dan berulang-ulang sehingga menimbulkan kerugian materil bagi si pemegang Hak Cipta khususnya dari sisi ekonomi yaitu kerugian finansial. Pemegang Hak Cipta selayaknya mendapatkan royalti atas karyanya yang digunakan orang lain guna kepentingan komersil. Oleh karena itu penulis ingin mengkaji lebih dalam terkait perlindungan hukum mengenai kewajiban pembayaran royalti dari perbuatan mengcover lagu dan berapa besar royali yang harus dibayarkan kepada pemilik lagu berdasarkan ketentuan Undang-Undang Hak Cipta. melalui tulisan ini, serta diharapkan dapat memberikan pemahaman yang sesuai dan digunakan sebagai acuan dalam pemecahan permasalahan di kemudian hari.

Penulisan jurnal ini dibuat secara orisinil dengan mengindari upaya plagiat dalam pembuatan karya ilmiah ini. tulisan ini secara orisinil merupakan pemikiran yang baru dan memiliki unsur pembaharuan didalam pembahasannya. Untuk menunjukkan orisinalitas penelitian, dapat ditampilkan dua jurnal ilmiah terdahulu yang menyerupai tulisan ini, antara lain:

1 Jurnal yang ditulis oleh Anak Gung Mirah Satria Dewi, tahun 2017, dipublis oleh jurnal hukum Kertha Semaya dengan judul "PERLINDUNGAN HUKUM HAK CIPTA TERHADAP COVER VERSION LAGU DI YOUTUBE"

2 Jurnal yang ditulis oleh Safina Meida Baqo dan Ranggalawe Surya Saladin, tahun 2016, dipublis oleh jurnaal hukum Universitas Indonesia dengan judul "PERMASALAHAN HUKUM HAK CIPTA PADA COVER VERSION TERHADAP LAGU YANG DIKOMERSIALISASIKAN"

Bedasarkan jurnal ilmiah terdahulu yang telah dijabarkan diatas, maka sudah barang tentu tidak terjadi usaha plagiat didalam penyusunannya, dan murni sebagai hasil pemikiran yang baru dan memiliki pembaharuan hukum.

\subsection{Rumusan Masalah}

Dari latar belakang tersebut, permasalahan yang diambil dalam tulisan ini yaitu:

1. Bagaimana pengaturan kewajiban pembayaran royalti terhadap perbuatan mengcover lagu musisi indonesia berdasarkan ketentuan Undang-Undang No. 28 Tahun 2014 tentang Hak Cipta?

\footnotetext{
${ }^{8}$ Gunawan Widjaja, 2003, Seri Hukum Bisnis Lisensi, Raja Grafindo Persada, Jakarta, h.8.
} 
2. Bagaimana akibat hukum apabila pihak yang melakukan cover lagu tidak membayar royalti kepada musisi pencipta lagu dan musik?

\subsection{Tujuan Penulisan}

Adapun tujuan yang diharapkan dalam penulisan ini untuk mengetahui pengaturan kewajiban pembayaran royalti terhadap perbuatan mengcover lagu musisi indonesia berdasarkan ketentuan Undang-Undang No. 28 Tahun 2014 tentang Hak Cipta dan akibat hukum yang ditimbulkan apabila para pihak menolak membayar royalti kepada musisi selaku pencipta lagu dan musik

\section{Metode Penelitian}

Kegiatan penulisan jurnal ilmiah memerlukan sebuah tata cara dalam penyusunannya yang biasa disebut metode penelitian. Metode digunakan sebagai dasar dalam melakukan analisa terhadap satu atau beberapa gejala hukum yang ada.Metode penelitian yang digunakan dalam tulisan ini adalah penelitian hukum normatif dengan menggunakan pendekatan perundang-undangan dan mengkaji dari literatur-literatur kepustakaan. Peraturan perundang-undangan yang digunakan dengan cara mengkaji ketentuan yang ada di dalam UndangUndang Nomor 28 Tahun 2014 tentang Hak Cipta. Penelitian hukum normatif artinya penelitian yang bertitik berat terhadap bahan hukum berupa aturan atau norma hukum positif dan menjadi bahan acuan utama dalam penelitian. ${ }^{9}$

Adapun pendekatan penelitian yang digunakan dalam pendekatan ini yaitu: pendekatan Undang-Undang (status Approach) dimana pada pendekatan ini digunakan untuk menelaah stiap undang-Undang dan regulasi yang berkaitan dengan permasalahan jurnal ini. Dan yang kedua menggunakan pendekatan konseptual (conseptual approach) yang beranjak dari perundang-undangan dan doktrin-doktrin yang berkembang dalam ilmu hukum, sehingga melahirkan pengertian hukum dan asas-asas hukum yang relevan pada permasalahan jurnal ini.

\section{Hasil dan Pembahasan}

3.1 Pengaturan Kewajiban Pembayaran Royalti Terhadap Perbuatan Mengcover Lagu Musisi Indonesia Dalam Undang-Undang No. 28 Tahun 2014 Tentang Hak Cipta.

Hak Cipta merupakan bagian dari Hak Kekayaan Intelektual yang didalamnya terdapat aturan dan hukum yang kemudian disebut sebagai Hukum Hak Kekayaan Intelektual. Hukum Hak Kekayaan Intelektual ini yaitu suatu hukum yang mengatur terkait hak-hak yuridis dari sebuah karya atau hasil ciptaan yang berdasar dari olah daya dan pikir manusia berkaitan dengan kepentingan yang bersifat moral dan ekonomi. ${ }^{10}$ Di Indonesia, Hak Cipta diatur dalam Undang-Undang No. 28 Tahun 2014 tentang Hak Cipta, sedangkan secara Internasional Hak Cipta telah diatur dalam Berne Convention, UUC (Universal Copyright Convention), dan TRIPs Agreement. Dalam Undang-Undang No. 28 Tahun 2014 tentang Hak Cipta Pasal 1 ayat (3) menyebutkan

9 Soerjono Soekanto \& Sri Mamuji, 2001, Penelitian Hukum Normatif Suatu Tinjauan Singkat, Raja Grafindo Persada, Jakarta, h. 51.

10 Suyud Margono, 2010, Hukum Hak Cipta Indonesia Teori Dan Analisis Harmonisasi Ketentuan World Trade Organization/WTOTRIPS Agreement, Ghalia Indonesia, Bogor, h. 35. 
tentang kriteria keaslian, bahwa "Ciptaan adalah hasil karya cipta di lapangan ilmu pengetahuan, seni dan sastra yang dihasilkan atas inspirasi, kemampuan, pikiran, imajinasi, kecerdasan keterampilan atau keahlian yang diekspresikan dalam bentuk nyata". Pernyataan sebuah keaslian yang menjadi kriteria suatu ciptaan merupakan patokan yang dilihat dari apakah benar-benar merupakan hasil murni dari pemikiran si pencipta.

Sebagai seorang pencipta atas hasil karya lagu yang dibuatnya dan dari lagu yang dibuat tersebut dapat memberikan hiburan bagi masyarakat maka sudah sepantasnya pencipta tersebut mendapatkan imbalan (royalti atas hasil karyanya, karena hal itu merupakan Hak Eksklusif yang dapat dimiliki oleh seorang pencipta dalam membuat suatu karya. Apabila Hak Eksklusif dari pencipta tersebut tidak dijalankan, maka dapat disebut bahwa terjadi suatu pelanggaran Hak Cipta. Sebagian dari Hak Eksklusif pemegang Hak Cipta adalah "hak untuk membuat salinan atau produksi ulang dari karya ciptaan sebelumnya, kemudian karya salinan tersebut dapat dijual kembali". Pemegang hak cipta juga dapat mengimpor dan mengekspor hasil karya ciptaannya, serta dapat menciptakan karya turunan (derivatif) atas ciptaannya, menampilkan dan memamerkan hasil karya ciptaannya kepada publik, dan menjual atau mengalihkan Hak Eksklusif tersebut kepada pihak lainnya. Hak khusus tersebut cenderung bersifat monopoli, artinya hanya pemilik karya asli yang dapat menggunakannya. ${ }^{11}$

Berdasarkan Pasal 4 Undang-Undang No. 28 Tahun 2014 tentang Hak Cipta menyatakan bahwa "Hak Cipta merupakan hak yang terdiri dari hak moral dan juga hak ekonomi". Hak moral adalah hak yang melekat pada diri Pencipta (termasuk pelaku) yang tidak dapat dihilangkan atau dihapus tanpa alasan apapun. Antara Pencipta dan Ciptaanya ada sifat kemanunggalan atau dengan kata lain ada hubungan integral di antara keduanya, hak moral juga merupakan simbol budaya hak pencipta. Sedangkan Hak ekonomi adalah hak yang didapatkan si pencipta terhadap hasil karyanya yaitu memberikan sebuah penghargaan, penghargaan itu dalam bentuk royalti, royalti adalah imbalan atas pemanfaatan Hak Ekonomi suatu Ciptaan atau Produk Hak Terkait yang diterima oleh pencipta atau pemilik hak terkait. ${ }^{12}$

Pada pasal 1 ayat 21 UU Hak Cipta, Royalti adalah imbalan atas pemanfaatan hak ekonomi suatu ciptaan atau produk terkait yang diterima oleh pencipta atau pemiilik hak terkait. Dalam pasal 40 angka 1 huruf d UU Hak Cipta lagu atau music merupakan hasil karya intelektual manusia yang mendapat perlindungan hokum. Musisi selaku pencipta lagu dan music memiliki hak ekonomi atas pengguanaan karya ciptaannya untuk kegiatan komersial, sehingga orang atau pihak yang menggunkan karya cipta lagu dan music orang lain untuk kepentingan komersial berkewajiban terlebih dahulu untuk menerima izin dari pencipta atau pemegang hak cipta lagu dan

11 Agung Sujatmiko, 2008, "Aspek Yuridis Lisensi Merek dan Persaingan Usaha". Jurnal Hukum Pro Justitia, Vol. 26, No. 2. h. 11-13

12 Habi Kusno, 2016, "Perlindungan Hukum Hak Cipta Terhadap Pencipta Lagu Yang Diunduh Melalui Internet", Jurnal Fakultas Hukum Universitas Lampung, Vol.10, No. 3, h. 491 
music tersebut. Kemudian pengguna (user) diwajibkan untuk membayar royalti kepada pencipta sebagai bentuk hak ekonomi yang didapatkan oleh pencipta atas pengguanaan karya ciptaannya untuk kepentingan komersial. ${ }^{13}$

Penggunaan lagu secara komersial tidak dianggap sebagai pelanggaran Hak Cipta asalkan pengguna memenuhi kewajiban mereka berdasarkan perjanjian dengan Lembaga Manajemen Kolektif (LMK) untuk membayar lagu royalty berdasarkan pasal 87 ayat (4) Undang-Undang No.28 Tahun 2014 tentang Hak Cipta. ${ }^{14}$ Mengenai ketentuan royalti dalam UU Hak Cipta tidak disebutkan hanya dijelaskan tentang pengertiannya saja serta dengan perjanjian lisensi maka si penerima lisensi tersebut harus membayar royalti kepada pemegang hak cipta terkait. Mengenai ketentuan royalti hanya dilakukan antara pengguna(User) dan pemegang hak cipta melalui Lembaga Menejemen Kolektif.

Pada pasal 87 UU Hak Cipta, Lembaga Manajemen Kolektif berperan sebagai perantara antara pengguna(User) dan pemegang hak cipta dalam memberikan izin(lisensi) kepada pengguna hak cipta serta pengguna(user) harus membayar royalty kepada pemegang hak cipta terkait. Adapun mekanisme pembayaran royalty menurut pasal 87 UU Hak Cipta yaitu:

1. Untuk mendapatkan hak ekonomi setiap pencipta, pemegang hak cipta, pemilik hak terkait menjadi lembaga manajemen kolektif agar dapat menarik imbalan yang wajar dari pengguna yang memanfaatkan hak cipta dan hak terkait dalam bentuk layanan public yang bersifat komersial.

2. Pengguna hak cipta dan hak terkait yang memanfaatkan hak sebagimana dimaksud pada ayat 1 membayar royalti kepada pencipta, pemegang hak cipta melalui lembaga manajemen kolektif.

3. Pengguna sebagaimana dimaksud pada ayat 1 membuat perjanjian dengan lembaga menejemen kolektif yang berisi kewajiban untuk membayar royalty atas hak cipta dan hak terkait yang digunakan.

Tidak dianggap sebagai pelanggaran UU ini, pemanfaatan ciptaan dan atau produk hak terkait secara komersial oleh pengguna sepanjang pengguna telah melakukan dan memenuhi kewajiban sesuai perjanjian dengan lembaga menejemen kolektif.

\subsection{Akibat Hukum Yang Ditimbulkan Apabila Para Pihak Tidak Membayar Royalti Kepada Musisi Selaku Pencipta Lagu dan Musik}

Pencipta dan pemegang Hak Cipta sebagaimana yang dimaksud dalam Pasal 8 Undang-Undang No. 28 Tahun 2014 tentang Hak Cipta, memiliki Hak Ekonomi untuk melakukan: “(1) Penerbitan Ciptaan; (2) Penggandaan Ciptaan dalam segala bentuk; (3) Penerjemah Ciptaan; (4) Pengadaptasian, pengaransemen, atau pentransformasian

13 Mahmuda Pancawisma Febriharini, 2016, “Eksistensi Hak Atas Kekayaan Intelektual Terhadap Hukum Siber". Jurnal Ilmiah: Fakultas Hukum Universitas 17 Agustus 194, Vol. 5, No. 1, h. 13-14.

14 Ni Made Dharmika Yogiswari, dan I Nyoman Mudana, 2020, "Perlindungan Hukum Hak Cipta Lagu Terhadap Kegiatan Aransemen", Jurnal Ilmiah Ilmu Hukum Kertha Semaya Hukum Udayana, Vol. 8, No. 5, h. 704 
ciptaan; (5) Pendistribusian Ciptaan atau salinannya; (6) Pertunjukan Ciptaan; (7) Pengumuman Ciptaan; (8) Komunikasi Ciptaan; (9) Penyewaan Ciptaan". Jadi setiap orang yang tanpa izin pencipta atau pemegang Hak Cipta dilarang melakukan penggandaan atau penggunaan karya cipta secara komersial.

Pengguna (users) dibedakan menjadi du yaitu: pengguna musik non komersial yang menggunakan lagu/musik hanya untuk didengarkan/dinikmati sendiri. Dan yang kedua yaitu pengguna musik komersial yang menggunakan lagu/musik untuk tujuan komersial dan bisa mendapatkan keuntungan atas lagu/musik tersebut, seperti: mall, karaoke, hotel, radio, dan cover lagu yang di upload pada media sosial. ${ }^{15}$

Harus diakui pelanggaran hak cipta dibidang musik tidak hanya merusak industri musik domestik, namun juga berdampak langsung kepada pencipta lagu/musik tersebut. Para pihak yang mengcover lagu ataupun yang membajak lagu tersebut sangat diuntungkan dari praktek ilegal ini karena mereka tidak mengeluarkan biaya untuk produksi. Pembajakan menjadi serius karena dilakukan dengan skala besar dan komersial. Terdapat tiga bentuk pembajakan karya cipta lagu, yaitu:

1 Plagiarism (plagiat), yaitu penjiplakan atas karya rekaman yang dilakukan dengan menggandakan secara keseluruhan album yang laku dipasaran dengan meniru persis isi, cover, dan kemasannya.

2 Bootleg, yaitu pembajakan karya rekaman suara yang dilakukan pada saat sorang penyanyi (musisi) yang tengah melakukan pertunjukkan (live show) di panggung tanpa izin dari musisi itu sendiri.

3 Pirate (pembajakan) yaitu bentuk perbanyakan karya rekaman yang dilakukan dengan merangkum berbagai lagu dari berbagai macam album rekaman suara yang dilindungi Hak Cipta.

Salah satu pelanggaran yang terjadi saat ini yaitu melakkan cover lagu dan di unggah pada media sosial tanpa seizin pemilik lagu/musik. Hal tersebut dikatakan melanggar hukum karena para pihak yang melakukan cover lagu tidak memiliki ijin lisensi dari pihak musisi selaku pemilik lagu dan juga cover lagu yang di unggah pada media internet banyak digunakan untuk kepentingan komersil sehingga telah terjadi indikasi pelanggaran terhadap Pasal 9 ayat (3) Undang-Undang No. 28 Tahun 2014 tentang Hak Cipta yang menyebutkan "Setiap orang yang tanpa izin Pencipta atau Pemegang hak cipta dilarang nenlakukan penggandaan dan/ atau penggunaan secara komersil ciptaan". Dengan sanksi sesuai dengan Pasal 113 ayat (3) Undang-undang hak Cipta menyatakan bahwa "setiap orang yang dengan tanpa hak dan/atau tanpa izin pencipta atau pemegang Hak Cipta melakukan pelanggaran hak ekonomi pencipta sebagaimana yang dimaksud dalam Pasal 9 ayat (1) huruf $a$, huruf b, huruf e, dan/atau huruf $g$ untuk penggunaan secara komersial dipidana dengan pidana penjara paling lama 4 (empat) tahun dan/atau pidana paling banyak Rp 1000.000.000,00 (satu miliar rupiah).

15 Desak Putu Lina maharani, dan I Gusti Ngurah Parwata, 2019, “Perlindungan Hak Cipta Terhadap Penggunaan Lagu Sebagai Suara Latar Video di Situs Youtube", Jurnal Ilmiah Ilmu Hukum Kertha Semaya Hukum Udayana, Vol. 7, No. 10, h. 6-8 
LMK selaku penerima kuasa dari pencipta lagu memiliki kewenangan untuk mengeluarkan surat peringatan apabila pihak pengcover lagu belum membayarkan royalti tepat pada waktunya sesuai dengan perjanjian yang dibuat, apabila setelah dikeluarkannya surat peringatan pembayaran royalti masih belum terpenuhi, maka LMK berwenang melaporkan pihak (users) tersebut ke pihak yang berwenang bahwa telah terjadi pelanggaran penggunaan hak cipta lagu dan musik untuk kepentingan komersial.

\section{Kesimpulan}

Di Indonesia, Hak Cipta diatur dalam Undang-Undang No. 28 Tahun 2014 tentang Hak Cipta. Sebagai seorang pencipta atas hasil karya lagu yang dibuatnya dan dari lagu yang dibuat tersebut dapat memberikan hiburan bagi masyarakat maka sudah sepantasnya pencipta tersebut mendapatkan imbalan (royalti atas hasil karyanya, karena hal itu merupakan Hak Eksklusif yang dapat dimiliki oleh seorang pencipta dalam membuat suatu karya. Apabila Hak Eksklusif dari pencipta tersebut tidak dijalankan, maka dapat disebut bahwa terjadi suatu pelanggaran Hak Cipta. Penggunaan lagu secara komersial tidak dianggap sebagai pelanggaran Hak Cipta asalkan pengguna memenuhi kewajiban mereka berdasarkan perjanjian dengan Lembaga Manajemen Kolektif (LMK) untuk membayar lagu royalty berdasarkan pasal 87 ayat (4) Undang-Undang No.28 Tahun 2014 tentang Hak Cipta. Pada pasal 87 UU Hak Cipta, Lembaga Manajemen Kolektif berperan sebagai perantara antara pengguna(User) dan pemegang hak cipta dalam memberikan izin(lisensi) kepada pengguna hak cipta serta pengguna(user) harus membayar royalty kepada pemegang hak cipta terkait.

Terdapat tiga bentuk pembajakan karya cipta lagu yaitu: Plagiarism, Pirate, Bootleg. Salah satu pelanggaran yang terjadi saat ini yaitu melakukan cover lagu dan di unggah pada media sosial tanpa seizin pemilik lagu/musik dan digunakan untuk kepentingan komersial. LMK selaku penerima kuasa dari pencipta lagu memiliki kewenangan untuk mengeluarkan surat peringatan apabila pihak pengcover lagu belum membayarkan royalti tepat pada waktunya sesuai dengan perjanjian yang dibuat. apabila setelah dikeluarkannya surat peringatan pembayaran royalti masih belum terpenuhi, maka LMK berwenang melaporkan pihak (users) tersebut ke pihak yang berwenang bahwa telah terjadi pelanggaran penggunaan hak cipta lagu dan musik untuk kepentingan komersial.

\section{DAFTAR PUSTAKA}

Buku.

Haris Munandar, dan Sally Sitanggang, Mengenal Hak Kekayaan Intelektual, Erlangga, Jakarta, 2012.

Ni Ketut Supasti Dharmawan, et. al., Harmonisasi Hukum Kekayaan Intelektual Indonesia, SWASTA NULUS, Denpasar, 2018.

Soerjono Soekanto \& Sri Mamuji, Penelitian Hukum Normatif Suatu Tinjauan Singkat, Raja Grafindo Persada, Jakarta, 2001.

Suyud Margono, Hukum Hak Cipta Indonesia Teori Dan Analisis Harmonisasi Ketentuan World Trade Organization/WTOTRIPS Agreement, Ghalia Indonesia, Bogor, 2010.

\section{Jurnal.}


Anak Agung Mirah Satria Dewi, 2017 "PERLINDUNGAN HUKUM HAK CIPTA TERHADAP COVER VERSION LAGU DI YOUTUBE", Jurnal Magister Hukum Udayana (Udayana Master Law Journal), Vol. 6, No. 4

Agung Sujatmiko, 2008, "Aspek Yuridis Lisensi Merek dan Persaingan Usaha”. Jurnal Hukum Pro Justitia, Vol. 26, No. 2

Desak Putu Lina maharani, dan I Gusti Ngurah Parwata, 2019, "Perlindungan Hak Cipta Terhadap Penggunaan Lagu Sebagai Suara Latar Video di Situs Youtube", Jurnal Ilmiah Ilmu Hukum Kertha Semaya Hukum Udayana, Vol. 7, No. 10.

Dyah Permata Budi Asri, 2018, "PERLINDUNGAN HUKUM PREVENTIF TERHADAP EKSPRESI BUDAYA TRADISIONAL DI DAERAH ISTIMEWA YOGYAKARTA BERDASARKAN UNDANG-UNDANG NOMOR 28 TAHUN 2014 TENTANG HAK CIPTA", Journal of Intellectual Property, Vol. 1, No. 1.

Habi Kusno, 2016, "Perlindungan Hukum Hak Cipta Terhadap Pencipta Lagu Yang Diunduh Melalui Internet", Jurnal Ilmiah: Fakultas Hukum Universitas Lampung, Vol. 10, No. 3.

Hoedi Prasetyo, dan Wahyudi Sutopo, 2018, "INDUSTRI 4.0: TELAAH KLASIFIKASI ASPEK DAN ARAH PERKEMBANGAN RISET". J@ti Undip: Jurnal Teknik Industri, Vol. 13, No. 1.

I Gusti Putu Agung Angga Aditya, dan A.A. Ketut Sukranatha, 2019, "PERLINDUNGAN HAK TERKAIT SEHUBUNGAN DENGAN COVER VERSION LAGU BERDASARKAN UNDANG-UNDANG HAK CIPTA". Kertha Semaya: Journal Ilmu Hukum, Vol.. 7, No. 1.

Kadek Julia Mahadewi, 2015 “Budaya Hukum Dalam Keberlakuan Undang-Undang Nomor 28 Tahun 2014 Tentang Hak Cipta Pada Pengerajin Perak Di Bali”, Jurnal Magister Hukum Udayana Vol. 4, No. 2.

Mahmuda Pancawisma Febriharini, 2016, “Eksistensi Hak Atas Kekayaan Intelektual Terhadap Hukum Siber". Jurnal Ilmiah: Fakultas Hukum Universitas 17 Agustus 194, Vol. 5, No. 1.

Mieke Yustia Ayu Ratna Sari, 2016, “PEMBANGUNAN KEKAYAAN INTELEKTUAL (KI) BERBASIS TEKNOLOGI INFORMASI", Unisbank Semarang.

Ni Made Dharmika Yogiswari, dan I Nyoman Mudana, 2020, “Perlindungan Hukum Hak Cipta Lagu Terhadap Kegiatan Aransemen", Jurnal Ilmiah Ilmu Hukum Kertha Semaya Hukum Udayana, Vol. 8, No. 5.

Putu Dina Amanda Swari, dan I Made Subawa. 2018, "PERLINDUNGAN HUKUM LAGU YANG DIUNGGAH TANPA IZIN PENCIPTA DI SITUS YOUTUBE". Jurnal Ilmiah Ilmu Hukum Kertha Semaya Hukum Udayana, Vol. 6, No. 10

Safina Meida Baqo \& Ranggalawe Suryasaladin, 2016, "Permasalahan Hukum Hak Cipta pada Cover Version terhadap Lagu yang Dikomersialisasikan". Jurnal Hukum Universitas Indonesia.

\section{Peraturan perundang-undangan}

Undang-Undang Nomor 28 Tahun 2014 tentang Hak Cipta. (Lembaran Negara Republik Indonesia Tahun 2014 No. 266, Tambahan Lembaran Negara Republik Indonesia No. 5599) 